\title{
The approach of conflict in Luke 12:49-59 through Form Criticism and its application in Nigerian churches
}

\begin{tabular}{|c|c|}
\hline \multicolumn{2}{|c|}{$\begin{array}{l}\text { Authors: } \\
\text { Ezichi A. Ituma } a^{1,2} \\
\text { Prince E. Peters } \\
\text { (1,2 }\end{array}$} \\
\hline \multicolumn{2}{|c|}{$\begin{array}{l}\text { Affiliations: } \\
{ }^{1} \text { Department of Religion and } \\
\text { Cultural Studies, Faculty of } \\
\text { the Social Sciences, } \\
\text { University of Nigeria, Nsukka, } \\
\text { Nigeria }\end{array}$} \\
\hline \multicolumn{2}{|c|}{$\begin{array}{l}{ }^{2} \text { Department of New } \\
\text { Testament and Related } \\
\text { Literature, Faculty of } \\
\text { Theology and Religion, } \\
\text { University of Pretoria, } \\
\text { Pretoria, South Africa }\end{array}$} \\
\hline \multicolumn{2}{|c|}{$\begin{array}{l}\text { Corresponding author: } \\
\text { Prince Peters, } \\
\text { prince.peters.195254@unn. } \\
\text { edu.ng }\end{array}$} \\
\hline \multicolumn{2}{|c|}{$\begin{array}{l}\text { Dates: } \\
\text { Received: } 18 \text { Jan. } 2021 \\
\text { Accepted: } 03 \text { June } 2021 \\
\text { Published: } 29 \text { Sept. } 2021\end{array}$} \\
\hline \multicolumn{2}{|c|}{$\begin{array}{l}\text { How to cite this article: } \\
\text { Ituma, E.A. \& Peters, P.E., } \\
\text { 2021, 'The approach of } \\
\text { conflict in Luke 12:49-59 } \\
\text { through Form Criticism and } \\
\text { its application in Nigerian } \\
\text { churches', Verbum et Ecclesia } \\
\text { 42(1), a2208. https://doi. } \\
\text { org/10.4102/ve.v42i1.2208 }\end{array}$} \\
\hline \multicolumn{2}{|c|}{$\begin{array}{l}\text { Copyright: } \\
\text { (C) 2021. The Authors. } \\
\text { Licensee: AOSIS. This } \\
\text { is licensed under the } \\
\text { Creative Commons } \\
\text { Attribution License. }\end{array}$} \\
\hline \multicolumn{2}{|l|}{ Read online: } \\
\hline aping: & $\begin{array}{l}\text { Scan this QR } \\
\text { code with your } \\
\text { smart phone or } \\
\text { mobile device } \\
\text { to read online. }\end{array}$ \\
\hline
\end{tabular}

Luke 12:49-59 contains two pericopes whose only bond of unity is conflict. The first pericope (49-53) deals with the kind of conflict best described as persecution because of Jesus, whereas, the first part of the second pericope (54-57) is a call for the Lukan community to understand various signs which mark a transition from the first to the second pericope. The second half of the second pericope (58-59) deals with inter-personal conflict among community members as it is seen and documented by the evangelist. In it, Jesus gives advice on how to avoid falling victim to legal justice. This research examines Jesus' stance in handling conflict, and to observe if the contemporary Christianity in Nigeria understands conflict management as Jesus did in Lk 12:49-59, and how far the church has applied Jesus' conflict management styles. The tools of exegesis and hermeneutics were employed to reconstruct the two pericopes and their various life situations.

Intradisciplinary and/or interdisciplinary implications: The study's implication is an approach with New Testament using Form Criticism to challenge the docility often seen in the (Nigerian) church each time there is a conflict situation. Peace and conflict study is analysed from the perspective of New Testament studies in order to cancel this stereotypical docility that is misunderstood as 'Christian pacifism'. It then argues that the life situation of the conflict (whether it is intra-mural or extra-mural) should guide Christians to make the right choice towards conflict management.

Keywords: conflict; church; Jesus; life situation; Nigeria.

\section{Introduction}

Scholars have lately increased their interest in discussing conflict (Leas 1992:vii), its causes and management. ${ }^{1}$ However, discussing conflict including its management from a biblical perspective ${ }^{2}$ and moreover from the person and the teachings of Jesus is an under-researched area. This study succinctly discusses conflict from the New Testament passage of Lk. 12:49-59, and to also understand Jesus' very opinions about conflict and conflict management from that passage. Jesus' opinion is assumed to be the dynamic approach to an equally dynamic conflict situation. The study asserts that the contemporary Nigerian Christianity's stereotypical approach to conflict and its management does not reflect Jesus' position. That is to say, the contemporary church in Nigeria does not seem to understand that Jesus' approach to conflict and its management is dynamic ${ }^{3}$; such ignorance has adversely affected the Nigerian church by making it a recipient of several violent attacks from rival religions when they are supposed to in fact defend themselves. A summary of the studied text (Lk. 12:49-59) would be necessary for further clarity. In the passage, Jesus talks about the fire he has come to cast upon the earth. He talks about the baptism he is meant to undergo and how distressed he is until it is accomplished. He asks a rhetorical question furthermore, 'do you think I came to bring peace on earth'; he supplied the answer as No! and added that he came to bring division. He talks about how such division would go to severe even family ties and make enemies of familial persons. Conclusively, he gives a personal note of advice on how to treat one's adversary before it becomes a legal matter, which is 'on-the-spot settlement'. This narrative leaves the reader of this text with the

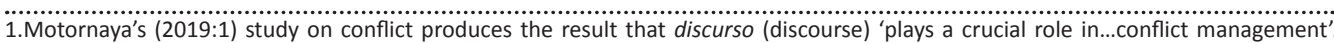
Kusztal (2002:232) uses 'a discourse-focused approach' to tackle organizational conflict. However, Fomin and Yakimova (2016:66) argue that 'conflicts normally occur in communication'. All these suggest that oral communication has a strong influence on starting conflict or managing it.

2.The church is said to have the belief that conflict is sinful (Jones 2000:14). This has therefore affected the quality of preparedness Church leaders receive in handling conflict in the Christian faith among church leaders. However, in Cunningham (1996:22) the 'sinful' attribution of conflict is cancelled. Oppenshaw, Nel and Louw (2018:3) insist that 'Conflict is inescapable' and is 'both good and necessary because it elicits different points of view, clears the air, and makes it possible to resolve extraordinarily complex issues'. See also Osterhaus, Jurkowski and Hahn (2005:14).

3.Cunningham (1996:39) opines that, 'it appears that [Jesus'] approach to conflict varied according to the situation'. 
understanding that Luke presented his Jesus as having discussed more than one kind of conflict ${ }^{4}$ and therefore, as a consequence more than one kind of conflict management is required. As the founder of Christian faith, Jesus' opinions in handling conflict become invaluable. ${ }^{5}$ This is based on the reason that he has been portrayed both by gospel evangelists and theologians as the Lamb and peaceful Messiah (Pontifical Council for Interreligious Dialogue World Council of Churches 2019:2). This portrayal in fact, has coloured the representation of Christianity as a nonviolent, ${ }^{6}$ non-partisan religion both intra-murally and extra-murally even in the face of affronts and unmitigated provocations and attacks. ${ }^{7}$ Such colouring has projected Christianity as a religion whose adherents 'must love their enemies because God loves everyone' Frändå (2016:26). ${ }^{8}$ It has been argued that 'the New Testament text, church tradition, and cultural mores converge in establishing non-violence as the pre-eminent mark of those who would be faithful followers of Christ' (Brown 2019:2). This necessitated that the person and teaching of Jesus, especially as it concerns conflict and conflict management should be subjected to critical study in order to confirm or affirm that the popular opinions attributed to Jesus in matter of handling persecutions and conflicts are true. This is where a study of Luke 12:49-59 comes in. The study aims to correct

4.Soares-Prabhu (2003:14) states that 'all four of our canonical gospels describe the ministry of Jesus as a time of intense and mounting conflict, culminating in his death upon the cross. The conflict they describe is pluriform'.

5.The scope of this article does not allow for the discussion of the cosmic conflict involving Jesus. However, for more studies on the cosmic conflict see Boyd (1997) White (2002) and White (1898).

6.The church's pacifist position has no strong basis in the NT or patristic writings (see Ambrose, De Officiis xxvii, 129; Augustine, Contra Faustum xxii, 74; Horsley 1986:24; Weaver 1992:35). Though Reid (2006:32) believes that certain portions of the NT text support non-violence, she however, sets out eight parables which she insists, talks about God as a violent being. This, Reid argues, puts Christians in a dilemma. She resolved the dilemma by setting out seven possible solutions of which the second reads as follows: 'A reading of Jesus as advocating active nonviolent resistance to evil could be an anachronistic reading' (Reid 2006:32). Reid's view is corroborated by this study's position. To lend credence to Reid's initial Reid's view is corrobora argument, Brown (2019:2) argues that the gospel, especially Jesus' Sermon on the Mount, is a pivotal text in forming the theology of non-violence. Klassen (1992:9) also discusses what he called 'enemy love' as foundational in Jesus and contained in the gospels. He believed that 'Luke and Matthew appear to be drawing from common source that included at least the "words: [agapate tous echthrous hyman 'Love your enemies."'. Horsley in Weaver (1992:35) rejects Jesus' assertive position on the non-violence stance by stating: 'Perhaps Jesus advocated non-violence. Ye there is little or no evidence that he ever directly or explicitly addressed this issue of violence vs. non-violence ... Since the sayings grouped with "love your enemies" do not refer to foreign or political enemies and do not focus on the question of violence, the lesser components of the usual picture of Jesus as advocate of non violence will not hold together.' Augustine (see Contra Faustum xxii, 74) and Ambrose's (see De Officiis xxvii, 129) writings are part of the patristic documents that prefer war to non-violence when it defends the dignity of man from onslaughts and annihilation.

7.The church has received several unmitigated and unprovoked attacks with Nigeria being one of the worst hit globally (Peters 2020b:1).

8. Exceptions follow such assertion though, when the likes of Juergensmeyer (2000) view all religions including Christianity as violence prone. Despite the fact that Vol (2002:6) criticises Juergensmeyer's opinion, Juergensmeyer may have set the sail for Küng's (2005:258) insistence that Christianity is not free from violence or bloodshed in the name of God. Küng (2005:259) blamed what he called Augustinian 'theory of the legitimate use of force to achieve spiritual ends' operational in Latin Christianity in the ancient church as responsible for the crusades and combating of heresies through inquisitions seen in Christianity that time. While one can say that Küng's opinion of Christianity and violence is over bloated (such over bloatedness could be to balance a long standing 20th century tradition of blaming every religion but Christianity of violence), Küng did not justify the contexts of Christianity in 'holy" wars. Opinions such as Küng's could be directly responsible for the attacks on wars. Opini hich such as teachings whe Fahey proposes four (4) traditions of war and peace in Christianity throughout it history. They include: Pacifism, Just War, Total War, and World Community. (Se War appeared in the late fourth and fifth centuries; Tolar War in the 11th century; War appeared in the late fourth and fifth centuries; Total War in the 11th century; and World Community began in the 16th century. All four positions continue today and are held by people who sincerely call themselves Christian' (Fahey 2018:8). as an aftermath of its exegesis and hermeneutics, any wrong impression associated with Jesus on conflict management. It also aims at stating that the pericopes under study carry more than one type of conflict management and to opine that different approaches (dynamism) were suggested by Jesus for the different kinds of conflicts.

\section{Life situations of Luke 12:49-59}

The Sitz im Leben of the studied text shows multiple life situations, though they are applied to different pericopes in the text. Form Criticism distinguishes three layers in textual analysis. The three life situations which Marthaler (2007) captures more vividly are:

(1) [T] he gospel accounts as we know them in the canon; (2) the local, ecclesial contexts in which the stories and sayings were first recalled, namely, the needs and interests of particular primitive Christian communities; and (3) the circumstances that surrounded an individual story or saying in the actual life of Jesus and its meaning'. These three stages in the formation of the gospel material are commonly referred to by German phrases: (1) Sitz im Evangelium; (2) Sitz im Leben der Kirche and (3) Sitz im Leben Jesu or Sitz im Historie. (p. 142)

Though these are strata in life situation studies, they can also apply to individual pericope or to multiple pericopes, just as two or all of them can complement each other in a pericope. ${ }^{9}$

\section{Sitz im Leben Jesu}

The situation in the life of Jesus is the context upon which the passage of Luke 12:49-53 is studied. Being 'the circumstances that surrounded an individual story or saying in the actual life of Jesus and its meaning' (Marthaler 2007:142), the text deserves a look, at first, from the Old Testament background. As the Christian Messiah whose Messianic mission contradicts Jewish Messianic expectations (see Evans 2006:19-20; Scott 1893:408), there was naturally a conflict set in his eschatological teaching as reflected in the pericope. One can identify the said pericope with Isaiah 8:14 and Micah 7:6, even though the expression of the Isaiah passage in LXX makes the interpretation of the passage with Jesus' statement in the studied pericope problematic. For example,

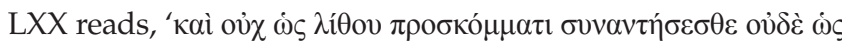
$\pi \varepsilon ́ \tau \rho \alpha \varsigma \pi \tau \dot{\omega} \mu \alpha \tau \iota^{\prime}$. That $\sigma u v \alpha v \tau \alpha \dot{\omega} \omega$ appears in present imperative passive, comes against the idea conveyed in MT. Despite that Isaiah 8:14 is textually unclear, it seems that this Messianic prophecy which alludes to 'a stone of stumbling and for a rock of offence' finds a common genre and root of context with Jesus' referent to himself as an agent of division. ${ }^{10}$ While the context of Luke 12:49-53 reflects Jesus assignment 'to cast

9.In his study of Matthew, Viljoen (2012:256) was one of those who believe that 'the Sitz im Leben der alten Kirche can indirectly be recognized in the Sitz im Leben Jesu as described in the Gospel material'. So far as it is hypothetically claimed that two life situations can indeed play out in a particular pericope in the study of Matthew, this hypothesis readily plays out in pericopes of other synoptic gospels.

10.Though Parihala and Busro (2020:4) interprets this 'division' as eschatological, yet religious distinctions which results from eschatological divisions are major causes of physical conflict (see Cunningham 1996:41). 
down upon the earth the fire of eschatological purgation' (Parihala \& Busro 2020:3) 'its purging flames are anticipating Jesus' coming fate and the divisive strife to come upon his disciples' (Parihala \& Busro 2020:3). 'We [must] see it as not only about the passion of Jesus, but also about the passion of the followers of Jesus facing contradiction and conflict' (Parihala \& Busro 2020:3). This conflict found its historical connection to the fall of Jerusalem (Parihala \& Busro 2020:3), a time when the Birkath ha-Minim was promulgated. ${ }^{11}$ Martyn is a major scholar who has argued that the Messianic Jews were excommunicated from the temple just as the promulgation of the Birkath ha-Minim was taking place (Klink 2008). This also goes with the persuading of 'other Jews to ostracize them in social and even in commercial life' (Alexander 1992:6). ${ }^{12}$ According to Peters (2020a):

This move was to incriminate [them in order to] bring God's curse on them by reciting three times daily the words 'God curse the Nazoreans' (Mayo 2006:331; Nadler 2012:2) in order to ostracize them from general synagogues. (p. 2)

\section{Sitz im Leben der Kirche}

Another set of discourses find themselves in the next pericope, the first of the two discourses reflect in the situation in the life of the Lukan community (Lk. 12:54-57). Here the Lukan church applies Jesus' admonition to the crowd, to a distinct condition namely, discernment of the time (Caird 1980:218); this was done through obvious eschatological signs contrasted with weather signs. Jesus chides the crowd for being expert weather forecasters, who are not able to discern the looming situation in the form of division which his teaching and its belief would cause. Palestine weather is said to be 'more even and has less variety than that in other lands' (Joy 1915:670) which makes it easy to predict; how much less an eschatological movement which has the propensity towards separating even familial bonds. Referring to the crowd as i does not carry the import of duplicity especially as it reflects in the passage of study, but derives its meaning from the

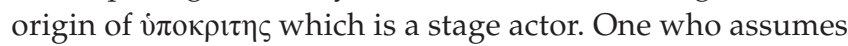
a role he is not, who reverts back to his real self when the audience is gone (Pope 2012:online). ov́к ớ $\delta \alpha \tau$ suggests that the crowd do not know what Jesus was informing them about, even though, in their religiosity, they assume to know it.

\section{Sitz im Evangelium}

In the same pericope where the previous life situation applied, another Sitz im Leben played out (Lk. 12:58-59), presenting double life situations in one pericope. It is possible that, according to Kloppenborg (1987:152-153) in Howes (2017:1) the two verses brandishes on the one hand,

11.There are however arguments that the Birkath ha-minim was enacted soon after 80 CE. See Truex (2001:6); Martyn (1979:57); Pritz (1988:103).

12.Brown (1966:380) in Doole (2021:389) dates this 'experience to around 90 CE', even after the fall of Jerusalem while Bernier (2013:138) sees threats to excommunicate Jesus' sympathisers from the synagogue as imminent within the time of Jesus himself. 'a sapiential admonition', and on the other a 'more typical of a prophetic judgment statement' respectively, yet, considering its parallel in Matthew 5:25-26, where it appeared as one of the aftermaths of the Beatitudes, or more properly, an antithesis, in Luke, the narrative was an obvious redaction by the Lucan evangelist to agree with the bulk of his teaching on conflict and conflict resolution. Howes (2017) brings out the true nature of conflict and conflict management in the pericope when he stated that:

[C]ausality is central to the rhetorical approach of the logion, which argues that if you fail to make amends with your legal opponents (the cause), you will be at the mercy of the legal system and end up in prison (the effect). (p. 4)

This cause and effect approach not only enlightens us about the possible outbreak of conflict between the debtor and the adversary, but also about a way to manage the conflict, which is out-of-court settlement. This life situation therefore relates to inter-personal conflict among community members (intra-mural conflict). By understanding that Luke redacted the passage to fit a particular form, there is therefore need to understand the correlation of Sitz im Evangelium and the redaction of a particular passage. This will lead us to ask, 'what did the evangelist mean to teach by recording this particular event in this particular setting?' (Kselman \& Witherup 2000:1137). This question undoubtedly points to an overlap of Form and Redaction criticisms in the text. The entire life situations in the two pericopes suggest that the story is of distorted sequence from different sources. ${ }^{13}$ Luke redacted the very sayings of Jesus on conflict to fit into a premeditated agenda, which is to set various precedents for his community on how to react to different conflict situations. And since two different styles of conflict appeared in two different contexts in the same Lukan passage, this study analyses Jesus' suggestions towards managing them and to apply those suggestions in the Nigerian church depending on the type of conflict that arises.

\section{Two conflict samples in Luke 12: 49-59 and their implications for modern conflict management by Nigerian churches}

The two pericopes in the passage of study provide us with two outstanding conflict samples which coincidentally are very relevant in today's conflict management; the Offensive and the Defensive strategies are duly suggested by Luke's Jesus. ${ }^{14}$ In the first pericope, there was the employment of an offensive approach by Jesus over and against whoever

13.Luke's scholars claim that it is a collection of logia from different sources: cf. Bock (1996), Luke, 1189-1190; Bovon (2007), Luca, 378-380; Wolter (2008) Lukasevangelium, 468. For details on the distorted sequence of the story in the two pericopes as found in the synoptic gospels, see Girolami, Luke 12:49-53 in Marcionite texts, 114-126.

14.The Offensive and Defensive conflict strategies seem to be directly responsible for the production of offense-defense balance which 'has become one of the most widely used theoretical constructs in international relations. The theory posits that technical and geographic factors affect whether the offense or defense has the advantage in any potential war, and that this will influence how two potential advantage in any potential war, and that this will influence how two potential
combatants prepare for conflict and react to a crisis' - Ryseff (2017:2). For more discussions on the offense-defence balance theory, see Jervis (1978:167-214). 
would find the message of his emerging kingdom both offensive and antagonistic. Although there was no instruction from Jesus towards violence or reprisals at worse, there was however, no attempt by Jesus to sue for either reconciliation or acquiescence. ${ }^{15}$ This suggests that, in a situation where the first kind of conflict appears (case of antagonism to the Christian or the church), his or their approach is self-defence. While a Christian in Nigeria or the church is not supposed to unleash violence against his adversaries, ${ }^{16}$ he is at the same time not to display cowardice before such adversaries by not defending himself robustly. The words of Jesus were matched with action somewhere (Jn. 2:13-16), an action which Cunningham (1996:39) see as confrontational. Ituma and Solomon (2012:21) consider Jesus' cleansing of the temple in Jonah 2:13-16 as a nonviolent act, yet one imbued with such boldness that the church leaders must follow suit. Therefore, Christians' dilemma of approach during conflict and war (Palmer n.d.:1), especially as it relates to Christians in Nigeria must be resolved into being steadfast against and firmly resisting the onslaught of the adversary. ${ }^{17}$ There are recorded cases in Nigeria of extreme conflicts between Christians and Muslims. The main cause of this conflict is the excessive persecution witnessed in the Muslim dominated north which is borne out of the desire to initiate Islamic dominance in the country, and even in the whole West African subregion (Kpughe 2017:2). The words of Joseph and Rothfuss (2012) supports this claim. They inform that:

Endemic religious intolerance, which has been the order of the day in northern Nigeria, and the struggle to reintroduce historic Islamic dominance in the region through the vehicle of religious extremism, are the twin drivers of Christian persecution in Nigeria. The daily experiences of Christians, who are marginalized and deprived of their citizens' rights in many parts of northern Nigeria, especially in the Sharia states, have been largely overshadowed by the frequent reports on sectarian violence by Boko Haram and 'clashes' between Muslims and Christians. (pp. 74-75)

Fisseha (2016:ii) confirms the relentless efforts by Moslem north to dominate the country with their religion through the agency of Boko Haram . He said, 'The Boko Haram (BH) Islamic fundamentalist emerged in Nigeria in 2002 with the idea of turning Nigeria into an Islamic country to be ruled by the Sharia law'. This was the same terrorist group which is said

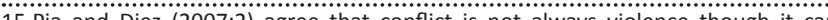
transcend to a justifiable violence as conflict intensifies. However, they realised that 'conflict can also lead to a new social or political organisation and therefore be productive if the parties involved are able to deal with their incompatibilities so productive if the parties involved are able to deal with their incompatibilities so
that such a new organisational form is achieved'. However, this study argues that,
new organisations formable as an aftermath of conflict also include religious, as new organisations formable as an aftermath of conflict also include religious, as
Christianity was one of such at its beginning. Neander (1847:70) describes how Christianity was one of such at its beginning. Neander (1847:70) describes how
Christ's statement of not having come to bring peace, but war aligns with Christianity's conflict with worldliness, which actually led to the emergence and spread of Christianity.

16.It is reported that Nigerian Christians face a high spate of persecution through the 'endemic religious intolerance, which has been the order of the day in northern Nigeria, and the struggle to reintroduce historic Islamic dominance in the region through the vehicle of religious extremism' (Joseph \& Rothfuss 2012:74).

17. Using 'data from Open Doors field workers and external experts to quantify and analyze persecution worldwide', World Watch List talks of 50 countries where Christians are persecuted for their faith yearly and Nigeria featured prominently (For detailed methodology visit ODUSA.org/WWLMethodology.) Also see World Watch List (2019:3) to be affiliated to al-Qaeda, and is suspected to communicate, train and share weapons with 'al-Qaeda in the Arabian Peninsula in Yemen, al-Shabaab in Somalia and al-Qaeda in the Islamic Maghreb (AQIM)' (Guitta \& Simcox 2014:6). All these violent situations against Nigerian Christianity have largely gone unchallenged (Peters 2020:2b). While it is true that 'some Christians have opted for a tough response, others have preferred a soft or conciliatory one' (Kpughe 2017:7) in managing the conflict with other religions like Islam, such tumultuous situation requires a bold, confrontational attitude as Jesus himself once did. It is recalled that:

Christ did not intend to teach that we are to see our families murdered, or be murdered ourselves; rather than to make resistance. The law of nature, and all laws, human and divine, justifies self-defense when life is in danger. It cannot surely be the intention to teach that a father should sit by coolly and see his family butchered by savages, and not be allowed to defend them. Neither natural nor revealed religion ever did, or ever can, inculcate this doctrine (Barne's commentary [https://biblehub. $\mathrm{com} /$ commentaries/ barnes/matthew/5.htm])

On this first conflict paradigm Luke was clear that the gospel they are to preach will generate unwarranted controversies that will lead to conflict and no efforts should be made towards quelling it. ${ }^{18}$ That necessitated the use of such words

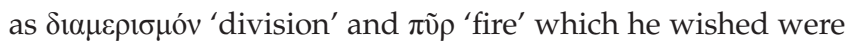
already kindled. It is hermeneutically lopsided to refer to this figurative designation $\pi \tilde{v} \rho$ (fire) as 'spiritual baptism', ${ }^{19}$ considering its Sitz im Leben; rather it fits the context to be considered as 'spiritual excitement' which initially leads to Jesus' death and then to the severance of familial bonds between his followers and their kin, a subject of offense indeed. This conflict precedes the kindling of the fire. ${ }^{20}$

In the succeeding pericope, Jesus advocated for defensive approach in the Lukan community's conflict management. Although the pericope reflects eschatological metaphor as earlier stated, it also relates to inter-personal conflict among community members. Jesus' switch of conflict management from offensive to defensive at this point, is probably explainable by his enquiry from his audience: how it is they cannot discern the dynamic situation of things as easily as they discern the dynamism of weather. 'To discern'

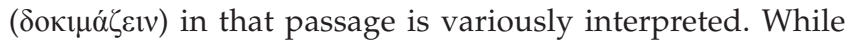
most authentic manuscripts (MSS) $\times \mathrm{B} \mathrm{L} \Theta$ read it as a

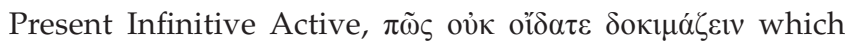
translates as 'how do you not know how to discern',

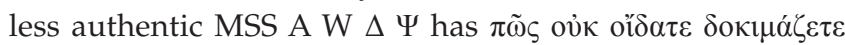

18.Girolami (2017:114) believes that Marcion's Jesus 'is not a peacemaker, but one that brings division - as Luke writes, or a sword as Matthew says'. Making reference to Sellew, he presents an exegetical conclusion on verse 52 concerning 'the division in a house - three against two and two against three - is closely tied to the meaning of the following verses about the divisions between generations'. This exegesis is important here because it entrenches the deepness of Jesus' influence towards global conflict; cf. Sellew (1987:617-668), 'Recontruction', 649: Luke 12:52, on the basis of some literary elements (emphatic position of esontai gar: apo tou nun is typically Lucan), it must be seen as editorial. Diamemerismenoi is added to better connect the two logia; eni is presumably a variant that Luke seems to preserve from the version of Q.

19.See https://biblehub.com/commentaries/cambridge/luke/12.htm.

20.See https://biblehub.com/commentaries/meyer/luke/12.htm \& https://biblehub. com/commentaries/bengel/luke/12.htm. 
(how do you not discern) with 'discern' in the Present Indicative Active plural. To make the text more complex,

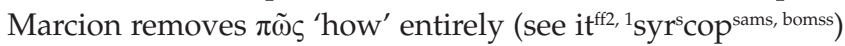
leaving the sentence as 'you do not discern'. Here, it is suggested that one who is in any dispute capable of dragging him to court should try to settle with his adversary before reaching the magistrate who presides over the court case. This adversary ( $\dot{\alpha} v \tau \imath \delta i ́ \kappa o \varsigma)$ is not to be taken as a mere opponent but an opponent at law; that is, 'a prosecuting attorney arguing a case-at-law' (https://biblehub.com/ greek/476.htm). This latter conflict style and its management relates to the gospel community as an intra-mural conflict situation. Jesus suggests an out-of-court settlement as a form of conflict resolution. This may have set a precedent for Paul who advocated same in 1 Corinthians 6:6. It requires a reconciliation move (see Matt. 5:23-24) and not bold resistance because of the familial (Christian) bond which hold the parties involved in the conflict together. Each time conflict between Christians arises, Jesus always advocates for 'non-request for one's rights'; even Paul advocated same too (1 Cor 6:7b). In Matthew chapter 10, which also discussed an intra-mural conflict (between Rabbinic Jews and Messianic Jews), he asked the aggrieved party to flee (v. 23). However, such non-resistance does not apply to his discussion on conflict in the previous pericope. These two distinct approaches to conflict management create the impression that Jesus wanted dynamism in handling conflict by his followers. It suggests that the approach to conflict resolution would differ depending on whether the conflict is intra-mural or extra-mural to the church. This rules out the case of stereotypical approach towards conflict management and resolution as witnessed in Nigerian churches.

\section{Conclusion}

The study of Luke 12:49-59 was done with the tool of Form Criticism which divided the passage into two pericopes and three life situations. It found in the various contexts, Jesus' address towards conflict and how to manage it. Although the passage had erstwhile been robustly studied as an eschatological text, yet the present study understands it from the angle that even an eschatological division has the tendency to lead to conflict. This was in line with Jesus' very own words which inform that his eschatological teaching will definitely separate people who share even familial bond, and such division has historically and contemporarily gone along with various degrees of conflict and even violence. When it is brought home to Nigeria, the belief in Jesus seems to be the major reason why other religions unleash attacks against Christians. The study proposes the application of dynamism to conflict management since the studied text makes provision for more than one type of conflict management.

Marcion's text tailor's itself to Metzger's (2002) assertion. He stated that:

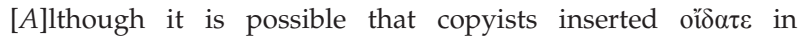
conformity with the preceding clause, it is more probable that they omitted the word in order to heighten Jesus' condemnation ('Why do you not know how to interpret ...?' implies a lack of knowledge; 'Why do you not interpret ...?' implies an unwillingness to use one's knowledge). (p. 136)

Jesus may have advocated for on-the-road settlement in order to avoid retaliatory justice (lex talionis), a dominant idea in biblical law, which was kicked against by the Pharisees but upheld by the Sadducees (May 1940-1941:438). His antithesis in Matthew confirms this. One may not be surprised that, Jesus held similar opinion with the Pharisees on the matter of lex talionis since scholars like Maccoby argue that Jesus himself was a Pharisee; see Maccoby (2004:37-42). But beyond the avoidance of retaliation, Jesus would have advocated for out-of-court reconciliation as a gesture of love, a virtue he well displayed, to those who accused him, who had earlier on, professed to love him Antiquities xviii, 64

\section{Acknowledgements Competing interests}

The authors declare that they have no financial or personal relationships that may have inappropriately influenced them in writing this article.

\section{Authors' contributions}

P.E.P. was responsible for the conceptualisation and writing up of the article. E.A.I. provided guidance and supervision.

\section{Ethical considerations}

The researchers were honest in the whole process of data collection and analysis, as well as objective in interpretation of the same data. They had respect for intellectual property, social responsibility and confidentiality. The research was, above all, non-discriminatory.

\section{Funding information}

This research received no specific grant from any funding agency in the public, commercial or not-for-profit sectors.

\section{Data availability}

Data sharing is not applicable to this article as no new data were created or analysed in this study.

\section{Disclaimer}

The views and opinions expressed in this article are those of the authors and do not necessarily reflect the official policy or position of any affiliated agency of the authors.

\section{References}

Alexander, P.S., 1992, “"The parting of the ways" from the perspective of Rabbinic Judaism', in J.D.G. Dunn (ed.) Jews and Christians: The parting of the ways A.D. 70 to $135, \mathrm{pp} .1-26$, Mohr, Tübingen. 
Bernier, J., 2013, Aposynagōgos and the historical Jesus in John: Rethinking the historicity of the Johannine expulsion passages, Brill, Leiden.

Bock, D.L., 1996, 'Luke', in R.W. Yarbrough \& J.W. Jipp (eds.), Baker exegetical commentary on the New Testament, p. 3, Baker Academic, Grand Rapids, MI.

Bovon, F., 2007, Vangelo di Luca II: Commento a 9.51-19.27, Commentario Paideia Nuovo Testamento 3/2, Brescia.

Boyd, G.A., 1997, God at war: The Bible and spiritual conflict, pp. 157-162, InterVarsity Press, Downers Grove, IL.

Brown, A.A., 2019, 'The violence of Jesus and the justice of God', Published dissertation presented to the Faculty of Theology at Stellenbosch University, Stellenbosch University, viewed 16 January 2021, from https://scholar.sun.ac.za.

Brown, R., 1966, The gospel according to John I, Doubleday, New York, NY.

Caird, G.B., 1980, The language and imagery of the Bible, The Westminster Press, Philadelphia, PA.

Cunningham, T.F., 1996, 'Conflict resolution strategies and the church: The church's role as an agent of social change in the political conflict in South Africa', PhD thesis, University of South Africa.

Doole, J.A., 2021, 'To be "an out-of-the-Synagoguer"', Journal for the Study of the New Testament 43(3), 389-410. https://doi.org/10.1177/0142064X20973905

Evans, C.A., 2006, 'Messianic hopes and Messianic figures in late antiquity', Journal of Greco-Roman Christianity and Judaism 3, 9-40.

Fahey, J.J., 2005, War and the Christian conscience: Where do you stand, Orbis Books, Maryknoll, NY.

Fahey, J.J., 2018, 'An overview of four traditions on war and peace in Christian history', The Journal of Social Encounters 2(1), 7-21.

Fisseha, M., 2016, 'The Nexus between religion and terrorism: An investigation into the Boko Haram killing activities in Nigeria', Master's thesis, Uppsala University.

Fomin, A.G. \& Yakimova, N.S., 2016, 'Communication strategies in conflict discourse: Cross-cultural experimental research', Procedia - Social and Behavioral Sciences 236, 65-70. https://doi.org/10.1016/j.sbspro.2016.12.021

Frändå, I., 2016, 'Interfaith dialogue and religious peace-building in the Middle East', An unpublished Master's dissertation submitted to Faculty of Theology, Uppsala University.

Girolami, M., 2017, 'Lk 12:49-53 in Marcionite texts', Liber Annuus 67, 113-126. https://doi.org/10.1484/J.LA.4.2019008

Guitta, O. \& Simcox, R., 2014, Terrorism in Nigeria the threat from Boko Haram and Ansaru, The Henry Jackson Society, London.

Horsley, R.A., 1986, "Ethics and exegesis: "Love your enemies" and the doctrine of non-violence', JAAR 54(1), 3-31. https://doi.org/10.1093/jaarel/LIV.1.3

Howes, L., 2017, “'Make an effort to get loose": Reconsidering the redaction of Q 12:58-59', Pharos Journal of Theology 98, 1-28.

Ituma, E.A. \& Solomon, E., 2012, 'Ethical implication of the use of whip in the cleansing o the temple According to John 2:13-16', International Journal of Theology \& Reformed Tradition 4, 14-23.

Jervis, R., 1978, 'Cooperation under the security dilemma', World Politics 30(2), 167-214. https://doi.org/10.2307/2009958

Jones, R.D., 2000, 'Resolving conflict Christ's way', The Journal of Biblical Counseling $19(1), 13-14$

Joseph, Y. \& Rothfuss, R., 2012, 'Threats to religious freedom in Nigeria analysis of a complex scenario', International Journal for Religious Freedom 5(1), 73-85.

Joy, A.H., 1915, 'Cloud', in J. Orr (Gen. ed.) The International standard Bible encyclopaedia, vol II, pp. 670-671, The Howard-Severance Company, Chicago, IL.

Juergensmeyer, M., 2000, Terror in the mind of God: The global rise of religious violence, University of California Press, Berkeley, CA.

Klassen, W., 1992, “'Love your enemies": Some reflections on the current status of research', in W.M. Swartley (ed.), The love of enemy and nonretaliation in the New Testament, pp. 1-31, Westminster/John Knox Press, Louisville, KY.

Klink, III. E.W., 2008, 'Expulsion from the Synagogue? Rethinking a Johannine anachronism', Tyndale Bulletin 59(1), 99-118.

Kloppenborg, J.S., 1987, The formation of Q: Trajectories in ancient wisdom collections, Fortress, Philadelphia, PA

Kpughe, L.M., 2017, 'Christian churches and the Boko Haram insurgency in Cameroon: Dilemmas and Responses', Religions 8(8), 143. https://doi.org/10.3390/ rel8080143

Kselman, J.S. \& Witherup, R.D., 2000, 'Modern New Testament criticism', in R.E. Brown, J.A. Fitzmyer, R.E. Murphy (eds.), New Jerome biblical commentary, pp. 1130-1145, Pearson, London.

Küng, H., 2005, 'Religion, violence and "holy wars"', International Review of the Red Cross 87(858), 253-268. https://doi.org/10.1017/\$1816383100181329

Kusztal, I.L., 2002, 'Discourses in the use and emergence of organizational conflict', Conflict Resolution Quarterly 20(2), 231-247. https://doi.org/10.1002/crq.21

Leas, S., 1992, 'Foreword', in D.W. Augsburger (ed.), Conflict mediation across cultures, pathways and patterns, pp. vii-ix, Westminster/John Knox Press, Louisville, KY.
Maccoby, H., 2004, 'Jesus the Pharisee', Jewish Quarterly 51(2), 37-42.

Marthaler, 2007, The Creed: The apostolic faith in contemporary theology, Twenty Third Publications, New London, CT.

Martyn, J.L., 1979, History \& theology in the fourth gospel, revised and enlarged Abingdon, Nashville, TN.

May, M., 1940-1941, 'Jewish criminal law and legal procedure', Journal of Crimina Law and Criminology 31(4), 438-447. https://doi.org/10.2307/1137565

Mayo, P.L., 2006, 'The role of the Birkath ha-Minimin in early Jewish-Christian relations: A re-examination of the evidence', Bulletin for Biblical Research 16(2), 325-343.

Metzger, B.M., 2002, The textual commentary on the Greek New Testament, 4th rev. edn., Deutsche Bibelgesellschaft, United Bible Societies, Stuttgart.

Motornaya, S.E., 2019, 'Gestión de situacionesconflictivas de la juventudmoderna: Discurso y elección de la estrategi', RevistaEspacios 40(17), 1-5.

Nadler, A., 2012, 'Do Jews curse Christians?', Jewish Ideas Daily, viewed 25 November 2017, from http://www.jewishideasdaily.com/4489/features/jews-curse-christians/.

Neander, A., 1847, General history of the Christian religion and church, transl. Joseph Torrey, Crocker \& Brewster, Boston, MA

Oppenshaw, D.L., Nel, M. \& Louw, L., 2018, 'Conflict resolution and reconciliation within congregations', HTS Teologiese Studies/Theological Studies 74(2), a4641. https://doi.org/10.4102/hts.v74i2.4641

Osterhaus, J.P., Jurkowski, J.M. \& Hahn, T.A., 2005, Thriving through ministry conflict, Zondervan Publishing House, Grand Rapids, MI.

Palmer, M., n.d., Christian responses to war, viewed 28 June 2020, from www.igrc.org/ files/tables/content/1000163/fields/files/f1b379de0e3248b79a3276269d7f0e82/ christian+responses+to+war.pdf.

Parihala, Y. \& Busro, B., 2020, 'Reclaiming Jesus as source of peace in Luke 12:49-53 through the perspective of religious pluralism in an Indonesian context', HTS Teologiese Studies/Theological Studies 76(4), a6088. https://doi.org/10.4102/hts. v76i4.6088

Peters, P.E., 2020a, 'Understanding persecution in Matthew 10:16-23 and its implication in the Nigerian church', HTS Teologiese Studies/Theological Studies 76(4), a5845. https://doi.org/10.4102/hts.v76i4.5845

Peters, P.E., 2020b, 'A critical look on Didache 1:4b and its reflection on the nonretaliation of the Nigerian church', HTS Teologiese Studies/Theological Studies 76(4), a6177. https://doi.org/10.4102/hts.v76i4.6177

Pia, E. \& Diez, T., 2007, 'Conflict and human rights: A theoretical framework', SHUR WP $1 / 7$, pp. 1-30, s.n., s.l.

Pontifical Council for Interreligious Dialogue World Council of Churches, 2019 Education for peace in a multi-religious world: A Christian perspective, WCC Publications, Geneva.

Pope, C., 2012, What does Jesus mean by hypocrisy? It's deeper than you think viewed 02 April 2021, from http://blog.adw.org/2012/02/what-does-jesus-meanby-hypocrisy-its-deeper-than-you-think/

Pritz, R.A., 1988, Nazarene Jewish Christianity: From the end of the New Testament period until its disappearance in the fourth century, E.J. Brill, Leiden.

Reid, B.E., 2006, Matthew's nonviolent Jesus and violent parables, Center for Christian Ethics at Baylor University, Waco, TX.

Ryseff, J.D., 2017, 'The maliciously formed packets of August: Cyberwarfare and the offense-defense balance', Centre for Strategic and International Studies, Washington, DC, pp. 1-18.

Scott, H.M., 1893, 'The teachings of Jesus and the teachings of the Jews in the time of Christ respecting the Messiah and his kingdom', The Biblical World 1(6), 408-419. https://doi.org/10.1086/471242

Sellew, P., 1987, 'Recontruction of Q 12:33-59', in K.H. Richards (ed.), Society of biblical literature: 1987 Seminar papers (26), pp. 617-668, SBLSP, Atlanta, GA.

Soares-Prabhu, G., 2003, 'Jesus and conflict', in G. Soares-Prabhu \& F.X. D'Sa (eds.) The dharma of Jesus, pp. 14-23, Orbis Books, Maryknoll, NY.

Truex, J.D., 2001, 'The problem of blasphemy: The fourth gospel and early Jewish understandings', PhD thesis, Department of Theology, University of Durham.

Viljoen, F.P., 2012, 'Matthew's Sitz im Leben and the emphasis on the Torah', Acto Theologica 32(2), 254-276. https://doi.org/10.4314/actat.v32i2.15

Volf, M., 2002, 'Christianity and Violence', in Boardman lectureship in Christian ethics, p. 2, viewed 16 January 2021, from http://repository.upenn.edu/boardman/2.

Weaver, D.J., 1992, 'Transforming nonresistance: From Lex Talionis to "do not resist the evil one"', in W.M. Swartley (ed.), The love of enemy and nonretaliation in the New Testament, pp. 32-71, Westminster/John Knox Press, Louisville, KY.

White, E.G., 1898, The desire of ages, Pacific Press, Mountain View, CA.

White, E.G., 2002, The great controversy, Global Distributors, Yonkers, NY.

Wolter, M., 2008, Das Lukasevangelium (HNT 5), Tübingen, Mohr Siebeck.

World Watch List, 2019, 'The fifty countries where it's most dangerous to follow Jesus', viewed 30 June 2020, from https://www.christianitytoday.com/news/2018/ january/top-50-christian-persecution-open-doorsworld-watch-list.html. 